\title{
Evaluation of Plant Extracts, Fungicides and Bio-agents against Early Blight Disease of Tomato Incited by Alternaria solani under in vitro and Field Conditions
}

\author{
Ravinder, Narender Singh*, Kushal Raj, Rakesh Kumar Chugh and Rakesh Sangwan \\ Chaudhary Charan Singh Haryana Agricultural University, Hisar, Haryana- 125004, India \\ *Corresponding author
}

\begin{abstract}
A B S T R A C T
Studies were undertaken to evaluate the plant extracts, fungicides and bio-agents against early blight disease of tomato caused by Alternaria solani under in vitro and vivo conditions. Among the four evaluated plant extracts against $A$. solani, neem leaf extract at $15 \%(w / v)$ was found to be most effective in inhibiting the mycelial growth of the pathogen with inhibition of 52.36 per cent, followed by combination of garlic clove and green chilli extract with the inhibition of 50.42 per cent. In case of evaluated fungicides, mancozeb $75 \mathrm{WP}$ at $0.2 \%$ found to be most effective, followed by hexaconazole $4 \%$ and zineb $68 \%(0.2 \%)$ with the per cent inhibition of $72.55 \%$ and $67.17 \%$ respectively. Trichoderma viride was found to be most superior against $A$. solani with the maximum mycelial inhibition of $37.49 \%$ among the bio-agents. Among different treatments, viz., plant extracts, fungicides and bio-agents under field conditions mancozeb 75WP at concentration of $0.2 \%$ was found to be most effective in managing the early blight disease with least per cent disease intensity of 20.46 per cent and 83.28 per cent decrease in disease over the control. This reduction of disease was reflected in terms of yield i.e maximum yield was also recorded from the same treatment $(18.5 \mathrm{~K} / \mathrm{plot})$ with 51.63 per cent increase in yield over the control plot.
\end{abstract}

\section{Introduction}

Tomato (Lycopersicon esculentum Mill.) is one of the most popular and widely grown vegetables throughout the world. It ranks second in importance among the vegetable crops after potato. It is greatly affected by many biotic and abiotic stresses. Gleason and Edmunds (2006) reported that tomato crop suffers from many fungal diseases
(Anthracnose, Early blight, Fusarium wilt, Late blight, Powdery mildew, damping-off (Pythium and Rhizoctonia) and fruit rot, bacterial diseases (Bacterial canker, Bacterial speck, Bacterial leaf spot, Bacterial wilt and Bacterial stem rot and fruit rot), viral diseases (Tomato leaf curl, Tomato mosaic and Tomato spotted wilt) and nematode diseases (Root-knot, Sting and Stubby-root). 
Among the fungal diseases, early blight incited by Alternaria solani is one of the major serious concerns due to huge yield losses in tomato. It is classified in the Phylum Ascomycota, sub divison Pezizomycotina, class Dothideomycetes and order Pleosporales. The fungus usually infects tomato, potato and eggplant. The disease is favoured by warm temperature with extended periods of leaf wetness, dew, rainfall and dense plantation. The plants are more susceptible to this pathogen during fruiting period (Cerkauskas, 2005, Momel and Pemezny, 2006). Although the disease is termed as early blight, but it may occur at all stages of development. Early blight is a threephases disease, which produce leaf spots, stem canker and fruit rot, but the foliar phase is more destructive which is responsible for significant economic losses sustained by tomato producer (Maiero and Barksdale, 1989). The early blight fungus can survive on the infected seeds for several days but it is still speculative whether the seed borne inoculum serve as a source of primary infection in the next season (Neergaard, 1945). The fungus over winters in infected plant debris, in or on the soil where it can survive at least one and perhaps several years.

Raja et al., (2016) studied the management of the early blight of tomato by using the different plant extracts and reported that among the all used plant extracts neem leaf extract showed maximum inhibition $(42.44 \%)$ over the Alternaria solani in all concentration (5, 10 and 15\%), followed by the Allium sativum with the mean inhibition of 40.20 per cent. Wani et al., (2017) evaluated twelve fungicides including systemic and nonsystemic, five bioagents and eight plant extracts in vitro against Exserohilum turcicum, the causal agent of turcicum leaf blight of maize and reported that two foliar sprays with non-systemic fungicide, mancozeb 75 WP @ 0.25 per cent reduced the diseased intensity from 20.45 per cent in control to 5.69 per cent and increased the grain yield from $45.20 \mathrm{q} /$ ha in control to $52.50 \mathrm{q} / \mathrm{ha}$; two foliar sprays with systemic fungicide, propiconazole 25 EC @ $0.1 \%$ reduced the diseased intensity to 6.11 per cent and increased the grain yield to $52.25 \mathrm{q} / \mathrm{ha}$; two foliar sprays with plant extract, neem oil @ 5\% reduced the diseased intensity to $10.90 \%$ and increased the grain yield to 49.90 $\mathrm{q} / \mathrm{ha}$ while seed treatment with bioagent, Trichoderma sp. $2 \times 10^{8} \mathrm{cfu} / \mathrm{g}$ @ $0.4 \%$ followed by two foliar sprays with mancozeb 75 WP @ $0.25 \%$ could further reduce the disease intensity to $5.40 \%$ and increase grain yield to $53.60 \mathrm{q} / \mathrm{ha}$.

The control of early blight disease has been accomplished primarily by the application of chemical fungicides, long crop rotation, pasteurizing seedbed with steam or fumigants (Jones et al., 1991) and efforts directed towards breeding resistant tomato cultivars. Very meagre information available on utilization of plant extracts, bio-agents and fungicides in managing the early blight disease of tomato. It is, therefore considered necessary to find out the remedial measures that could be cheap and eco-friendly for management of early blight of tomato.

\section{Materials and Methods}

\section{In vitro evaluation of botanicals/plant extracts against early blight disease of tomato caused by Alternaria solani}

The efficacy of four botanicals/plant extracts viz., neem leaf extract, neem seed kernel extract, green chilli fruit extract and garlic clove + green chilli fruit extract @ concentrations of 5, 10 and 15 (w/v\%) of each extract against Alternaria solani were tested in vitro using the standard procedure of poison food technique as given by Mayer (1962). 
In vivo evaluation of botanicals/plant extracts for against Alternaria solani pathogen

To determine the efficacy of two effective plant extracts viz., neem leaf extract and garlic clove + green chilli fruit extract @ concentrations of $15(\mathrm{w} / \mathrm{v} \%)$ of each extract against the early blight of tomato, field trial were conducted at experimental area of the Department of Plant Pathology, CCS HAU, Hisar in Rabi, 2017-18 with a susceptible variety i.e Selection-7. Forty five days old seedlings were transplanted with a spacing of $50 \mathrm{~cm} \times 50 \mathrm{~cm}$. The plot size was $2.0 \mathrm{~m} \times 2.0$ $\mathrm{m}$ with three replications. Thirty days after transplanting, plants were inoculated with the spore suspension of $A$. solani having $1 \times 10^{6}$ spores per $\mathrm{ml}$ of sterilized water. The spore suspension was sprayed during evening hours for easy establishment of the pathogen. The plant extracts were sprayed after one day of spraying of spore suspension in their respective plot at 10 days interval between 30 to 50 days after transplanting. Only sterilized water was sprayed in control plots. Observations on disease severity were recorded at 10 days interval after spraying last plant extracts on the basis of 7 leaves randomly taken from each plot. Per cent disease intensity (PDI) was worked out by using 0 -5 scale (Mayee and Datar, 1986). The per cent disease control over check was worked out by following formula.

Per cent disease control $=$

PDI in control - PDI in treatment

PDI in control

x 100

In vitro evaluation of bio-agents against $A$. solani

The efficacy of two bio-agents namely, Trichoderma viride and Pseudomonas fluorescence@ concentrations of 0.1,0.5 and 2 (v/v) of each bio-agent was tested against $A$. solani by inhibition of mycelial growth on the PDA media using culture filtrate technique under in vitro condition.

In vivo evaluation of bio-agents against $A$. solani

To determine the efficacy of $T$. viride at 2 per cent concentration against early blight of tomato, the field trial was conducted at experimental area of the Department of Plant Pathology, CCS HAU, Hisar in Rabi season, 2017-18 with a susceptible variety (Selection7). Forty five days old seedlings were transplanted with a spacing of $50 \mathrm{~cm} \times 50 \mathrm{~cm}$ in Randomized Block Design. The plot size was $2.0 \mathrm{~m} \times 2.0 \mathrm{~m}$ with three replications. Thirty days after transplanting, plants were inoculated with the spore suspension of $A$. solani having $1 \times 10^{6}$ spores per $\mathrm{ml}$ of sterilized water. The spore suspension was sprayed during evening hours for easy establishment of the pathogen. The culture filtrate of $T$. viride was sprayed after one day of spraying of spore suspension in their respective plots at 10 days interval between 30 to 50 days after transplanting and only sterilized water was sprayed in control plots. Observations on disease severity were recorded at 10 days interval after spraying last plant extracts on the basis of 7 leaves randomly taken from each plot. Per cent disease intensity was worked out by using 0 5 scale (Mayee and Datar, 1986). The per cent disease control over control was worked out by following formula.

Per cent disease control $=$

PDI in control - PDI in treatment

PDI in control $\times 100$

\section{In vitro evaluation of fungicides}

The efficacy of different fungicides viz., Mancozeb (75\% WP), Propineb (70\% WP), Propiconazole (25\% EC) and Hexaconazole 
+Zineb (72\% WP) @ concentrations of 0.05 , 0.1 and $0.2(\mathrm{w} / \mathrm{v} \%)$ of each fungicides was evaluated against $A$. solani for inhibition of colony growth on the potato dextrose agar medium using poisoned food technique under in vitro conditions.

$I=\frac{C-T}{C} \times 100$

Where,

$\mathrm{I}=$ Per cent inhibition

$\mathrm{C}=$ Radial growth in control

$\mathrm{T}=$ Radial growth in treatment (fungicide)

\section{In vivo evaluation of fungicides}

To determine the efficacy of two effective fungicides against early blight disease, field trial was conducted at experimental area of the Department of Plant Pathology, CCS HAU, Hisar in Rabi (2017-18) with a susceptible variety i.e. Selection-7. Forty five days old seedlings were transplanted with a spacing of $50 \mathrm{~cm} \times 50 \mathrm{~cm}$. Thirty days after transplanting plants were inoculated with the spore suspension of $A$. solani having $1 \times 10^{6}$ spores per $\mathrm{ml}$ of sterilized water. The effective fungicides under in vitro conditions namely, Mancozeb (75\% WP) @ 0.2\% and Hexaconazole + Zineb (72\% WP) @ 0.2\% were sprayed after 24 hours of spraying of inoculum in respective plots at 10 days interval between 30 to 50 days after transplanting and observations on disease severity were recorded at 10 days interval after spraying last fungicide on the basis of 7 leaves randomly taken from each plot by using 0-5 scale (Mayee and Datar, 1986). The per cent disease control over control was calculated as

Per cent disease control $=$

PDI in control - PDI in treatment

PDI in control $\times 100$
The fruit yield in each plot was recorded separately. Increase in fruit yield over control was also calculated.

\section{Results and Discussion}

Evaluation of plant extracts, bio-agents and fungicides against $A$. solani under in vitro and field conditions

The efficacy of different treatments viz., plant extracts, bio-agents and fungicides were evaluated under in vitro condition at their respective doses. Among the four evaluated plant extracts against $A$. solani, neem leaf extract at $15 \% \mathrm{w} / \mathrm{v}$ was found to be most effective in inhibiting the mycelial growth of the pathogen with inhibition of 52.36 per cent, followed by combination of garlic clove and green chili extract with the inhibition of 50.42 per cent. In case of evaluated fungicides, mancozeb $75 \mathrm{WP}$ at $0.2 \%$ found to be most effective, followed by hexaconazole $4 \%$ and zineb $68 \%(0.2 \%)$ with the per cent inhibition of $72.55 \%$ and $67.17 \%$ respectively. Trichoderma viride was found to be most superior against $A$. solani with the maximum mycelial inhibition of $37.49 \%$ among the bioagents. (Table 1) Several workers have reported the efficacy of many plant extracts, fungicides and bioagents against the $A$. solani under in vitro conditions. Kamble et al., (2000) tested six fungicides against $A$. alternate, under in vitro conditions. They reported that mancozeb was highly effective in inhibiting the mycelial growth followed by copper oxychloride and iprodine at 1000, 2000 and 3000 ppm.

Two plants extract (neem leaf extract and garlic clove and green chili extract), a bioagent (Trichoderma viride) and two fungicides (mancozeb 75WP and hexaconazole $4 \%$ and zineb $68 \%$ ), which were found most effective under in vitro were sprayed at their respective doses in the given schedule under the field conditions. 
Table.1 Evaluation of plant extracts, fungicides and bio-agents against Alternaria solani under in vitro conditions

\begin{tabular}{|c|c|c|c|}
\hline Treatment & Dose $(\%)$ & \multicolumn{2}{|c|}{$\begin{array}{c}\text { Per cent inhibition } \\
(\%)\end{array}$} \\
\hline T1 & Neem leaf extract & 5 & $42.88(40.89)^{*}$ \\
\hline $\mathbf{T 2}$ & Neem leaf extract & 10 & $57.14(49.09)$ \\
\hline T3 & Neem leaf extract & 15 & $62.73(52.36)$ \\
\hline T4 & Neem seed kernels extract & 5 & $40.47(39.49)$ \\
\hline T5 & Neem seed kernels extract & 10 & $47.29(43.43)$ \\
\hline T6 & Neem seed kernels extract & 15 & $54.70(47.68)$ \\
\hline T7 & Green chili fruit extract & 5 & $37.42(37.70)$ \\
\hline T8 & Green chili fruit extract & 10 & $45.21(42.23)$ \\
\hline T9 & Green chili fruit extract & 15 & $51.98(46.12)$ \\
\hline T10 & Garlic clove + Green chilli fruit extract & 5 & $39.83(39.11)$ \\
\hline T11 & Garlic clove + Green chilli fruit extract & 10 & $52.45(46.39)$ \\
\hline T12 & Garlic clove + Green chilli fruit extract & 15 & $59.43(50.42)$ \\
\hline T13 & mancozeb 75\% WP & 0.05 & $80.62(63.87)$ \\
\hline T14 & mancozeb $75 \%$ WP & 0.1 & $83.98(66.45)$ \\
\hline T15 & mancozeb $75 \%$ WP & 0.2 & $91.02(72.55)$ \\
\hline T16 & propineb $70 \% \mathrm{WP}$ & 0.05 & $68.42(55.79)$ \\
\hline T17 & propineb $70 \% \mathrm{WP}$ & 0.1 & $71.11(57.47)$ \\
\hline T18 & propineb $70 \% \mathrm{WP}$ & 0.2 & $73.44(58.96)$ \\
\hline T19 & propiconazole $25 \% \mathrm{EC}$ & 0.05 & $71.96(58.02)$ \\
\hline T20 & propiconazole $25 \% \mathrm{EC}$ & 0.1 & $75.57(60.36)$ \\
\hline T21 & propiconazole $25 \% \mathrm{EC}$ & 0.2 & $83.32(65.89)$ \\
\hline T22 & hexaconazole +zineb (72\% WP) & 0.05 & $77.07(61.38)$ \\
\hline $\mathbf{T 2 3}$ & hexaconazole +zineb (72\% WP) & 0.1 & $81.54(64.56)$ \\
\hline T24 & hexaconazole +zineb (72\% WP) & 0.2 & $84.92(67.17)$ \\
\hline T25 & Trichoderma viride & 0.1 & $23.67(29.09)$ \\
\hline T26 & Trichoderma viride & 0.5 & $27.00(31.29)$ \\
\hline T27 & Trichoderma viride & 2 & $37.06(37.49)$ \\
\hline T28 & Pseudomonas fluorescence & 0.1 & $21.00(27.24)$ \\
\hline T29 & Pseudomonas fluorescence & 0.5 & $26.29(30.83)$ \\
\hline T30 & Pseudomonas fluorescence & 2 & $30.30(33.38)$ \\
\hline T31 & Control & - & 0.00 \\
\hline & $\begin{array}{r}\text { C.D. at } 5 \% \\
\operatorname{SE}(\mathrm{m})\end{array}$ & & $\begin{array}{l}2.07 \\
0.73\end{array}$ \\
\hline
\end{tabular}


Table.2 Evaluation of plant extracts, bio-agents and fungicides against early blight disease under field conditions

\begin{tabular}{|c|l|c|c|c|c|c|}
\hline S.No. & Treatment & $\begin{array}{c}\text { Dose } \\
(\mathbf{\%})\end{array}$ & *PDI (\%) & $\begin{array}{c}\text { PDOC } \\
(\mathbf{\%})\end{array}$ & $\begin{array}{c}* \text { Yield } \\
(\mathbf{K g} / \mathbf{p l o t})\end{array}$ & $\begin{array}{c}\text { IYOC } \\
(\mathbf{\%})\end{array}$ \\
\hline $\mathbf{1 .}$ & Neem leaf extract & 15 & $28.71(32.34)^{*}$ & 61.34 & 16.8 & 37.70 \\
\hline $\mathbf{2 .}$ & Garlic clove + Green chili fruit extract & 15 & $32.42(34.68)$ & 56.35 & 15.5 & 27.04 \\
\hline $\mathbf{3 .}$ & mancozeb 75\% WP & 0.2 & $12.43(20.46)$ & 83.28 & 18.5 & 51.63 \\
\hline $\mathbf{4 .}$ & hexaconazole +zineb (72\% WP) & 0.2 & $19.86(26.36)$ & 74.62 & 16.5 & 35.24 \\
\hline $\mathbf{5 .}$ & Trichoderma viride & 2 & $48.57(44.16)$ & 34.61 & 15.8 & 29.50 \\
\hline $\mathbf{6 .}$ & Control & - & $74.28(59.58)$ & & 12.2 & \\
\hline & C.D. & 1.20 & & & & \\
\hline
\end{tabular}

*Mean of three replications, *values in parentheses are angular transformed, PDOC-per cent decrease in disease over control, IYOC-per cent increase in yield over control.

It was observed that among different treatments, mancozeb $75 \mathrm{WP}$ at concentration of $0.2 \%$ was found to be most effective in managing the early blight disease with least per cent disease intensity of 20.46 per cent and 83.28 per cent decrease in disease over the control. This reduction of disease was reflected in terms of yield i.e. maximum yield was also recorded from the same treatment $(18.5 \mathrm{~K} / \mathrm{plot})$ with 51.63 per cent increase in yield over the control plot. However, Trichoderma viride was not found so effective in managing the early blight disease. Varma et al., (2008) reported that foliar spray of Trichoderma viride, 24hours before challenge inoculation with the Alternaria solani, was found effective in reducing the disease severity under screen house conditions. They have also reported that effective management of early blight disease achieved with three sprays of mancozeb (2000ppm) under field condition (Table 2). Mancozeb (75\% WP) and hexaconazole and zineb ( $72 \%$ WP) were found to be most effective among the fungicides under in vitro condition. Two plants extract (neem leaf extract and combination of garlic clove and green chili extract) and a bio-agent (Trichoderma viride) was also found effective in inhibiting the mycelial growth of $A$. solani among the plant extracts and bioagents, respectively. In field conditions, mancozeb 75WP was found to be most effective in reducing the early blight disease and increasing the fruits yield.

\section{References}

Cerkauskas, R. (2005). Early blight. AVRDC, the world vegetable centre, www.avrdc.org .

Gleason, M.L. and Edmunds, B.A. (2006). Tomato diseases and disorders. Plant Pathology, Iowa State University, University Extension, 1-12.

Jones, J.B., Jones, J.P., Stall, R. E., Zitter, T.A. and John Paul Jones, R.E. (1991). Compendium of tomato diseases. American Phytopathology Society, 89: 9-25.

Kamble, P.U., Ramiah, M. and Patil, D.V. (2000). Efficacy of fungicides in controlling leaf spot disease of tomato caused by Alternaria alternata (Fr.) Kessiler. Journal Soils and Crops, 10(1): 36-38.

Maiero, M.T. and Barksdale, T.H. (1989). Combining ability estimates for early 
blight resistance in tomato. Journal of American Society for Horticulture Science, 114: 118-121.

Mayee, C.D. and Datar, V.V. (1986). Phytopatholometry Technical Bulletin1. Marathwad Agricultural University, Parabhani, pp. 25.

Mayer, C.R. (1962). Response of selected Rhizoctonia solani isolates to different soil chemical tests. Phytopathology, 52: 19 .

Momel, T.M. and Pemezny, K.L. (2006). Florida plant disease management guide: Tomato. Florida Cooperation Extensive Service, Institute of Food and Agriculture Sciences, Gaineville, 32611. Neergaard, P. (1945). Danish species of Alternaria and Stemphylium, Hamphry Millfor. Oxford University Press, London, pp. 566.
Raza, W., Ghazanfar, M.U., Iftikhar, Y., Ahmed, K.S., Haider, N. and Rasheed, M.H. (2016). Management of early blight of tomato through the use of plant extracts. International Journal of Zoology Studies, 1(5): 1-4.

Varma, P.K., S.K. Gandhi and S. Singh (2008). Biological control of Alternaria solani, the causal agent of early blight of tomato. Journal Biological Control, 22(1): 67-72.

Wani, T.A., Ahmad, M. and Anwar A. (2017). Evaluation of fungicides, bioagents and plant extracts against Exserohilum turcicum causing Turcicum leaf blight of maize. International Journal of Current Microbiology and Applied Sciences, 6(8): 2754-2762.

\section{How to cite this article:}

Ravinder, Narender Singh, Kushal Raj, Rakesh Kumar Chugh and Rakesh Sangwan. 2020. Evaluation of Plant Extracts, Fungicides and Bio-agents against Early Blight Disease of Tomato Incited by Alternaria solani under in vitro and Field Conditions. Int.J.Curr.Microbiol.App.Sci. 9(04): 1914-1920. doi: https://doi.org/10.20546/ijcmas.2020.904.227 